\title{
INFLUENCE OF TEACHER CHARACTERISTICS ON STUDENTS' ACADEMIC ACHIEVEMENT AMONG SENIOR HIGH SCHOOLS IN OGAN KOMERING ULU
}

\author{
Silfi Sanda \\ SMA Negeri 4 OKU, South Sumatera
}

\begin{abstract}
In UU No. 14/2005 state that all teacher should have pedagogy, social, professional and personality competencies. One of the important competencies is personality competence. According to Moorhead \& Griffin (2010), there are five traits which is related to the organizational behavior called "big five personality traits". Those are agreeableness, conscientiousness, negative emotionality, extraversion and openness. The purpose of this study was to establish the relationship between teacher characteristics and students' academic achievement. The study was guided by Education Production Function theory (EPF) which connects student academic achievement to teacher characteristics. The study was conducted in Ogan Komering Ulu, the target population comprised of teachers of all 20 senior high schools. The study applied a causal comparative research design. A questionnaire was used for data collection. Data was analyzed using descriptive and inferential statistical techniques. The study findings suggest that there was no significant relationship between teacher qualification and student academic achievement.
\end{abstract}

Keywords: Teacher characteristics, academic achievement, experience and qualification

\section{INTRODUCTION}

Education is widely regarded as a basic human right, a key to enlightenment, and a source of wealth and power (Mugenda \& Mugenda: 1999). Ali (2009) observes that there was statistically significant relationship between teacher characteristics and student academic achievement. 
Akinsolu (2010) asserts that availability of qualified teachers determined the performance of students in schools. Coonen (1987) emphasizes that teachers involved in in-service training were more effective in classrooms as compared to teachers who had not undergone training. Wirth \& Perkins (2013) indicate that teacher's attitude contributed significantly to student attention in classrooms whereas Adesoji \& Olatunbosun (2008) illustrates that student attitude was related to teacher characteristics. This therefore meant that teacher's attitude directly affected students' attitude. On teacher personality, Adu \& Olatundun (2007) contend that teachers' characteristics are strong determinants of students' performance in Senior High Schools.

In UU No. 14/2005 state that all teacher should have pedagogy, social, professional and personality competencies. One of the important competencies is personality competence. According to Moorhead \& Griffin (2010), there are five traits which is related to the organizational behavior called "big five personality traits". Those are agreeableness, conscientiousness, negative emotionality, extraversion and openness. Therefore, this study is aim at verifying whether "big five personality" could be implemented to measure teachers personality. Beside, which personality factors could be the best as a determinant factor for teachers performance. Putrawan, et al. (2012) found out that personality factors could not be neglected in school principal in improving the quality of school management.

The purpose of this study was to establish the relationship between teacher characteristics and students' academic achievement. This study therefore sought to investigate the influence of teacher characteristics in influencing students' performance.

\section{CONCEPT OFTEACHER CHARACTERISTICS}

The term "teacher characteristics" can be referred to as qualities that can be measured with tests or derived from their academic or professional records. They indicate that teacher characteristics does not generally refer to the direct observation of their influence on students' learning in terms of either students' test performance or teaching behaviors. Rather, the approaches dealt within the scope of this research are those that fall traditionally into the province of personnel psychology or personnel selection. This review deals with those characteristics of teachers that might be identified and used in the initial hiring of teachers to increase their students' achievement. 
Ashton(1996) indicates that these characteristics could include qualities of teachers that are viewed as personal - such as mental ability, age, gender - or as "experiential" - such as certification status, educational background, previous teaching experience and the like. Some characteristics are combinations - in unknown amounts - of personal and experiential qualities, for example; candidates' performance on teacher-certification tests such as the national teacher examinations and state-mandated tests.

\section{TEACHER QUALIFICATION AND STUDENT ACADEMIC ACHIEVEMENT}

Darling - Hammond (1998) defines well qualified teacher as one who was fully certified and held the equivalent of a major in the field being taught. Although the formal qualification of teachers is an important indicator for their knowledge and competence in teaching, it has only limited utility in analyzing how well prepared teachers are for what they have to teach in schools. More detailed knowledge of the courses they have taken during their training needs to be compared to the actual content and skills required to teach the high school's curriculum.

Ruthland \& Bremer (2002) refer to teacher qualification in two ways traditional and alternative qualification routes. Traditional certification is when an individual completes an undergraduate degree or post graduate program in education. Alternative routes of certification are based on coursework in pedagogy and subject area without a degree in education. Hardy \& Smith (2006) cite short term activities such as mentoring, peer evaluations and workshops as ways other than formal qualifications for improving teaching. More often graduates teachers with first degree content go into teaching if they cannot find another job right away. Although they often get somewhat lower salary than a fully qualified teacher; they choose not to enroll in the one year post- graduate professional training and therefore lack a basic foundation for teaching.

Huang \& Moon (2009) documents that teacher qualification accounted for approximately 40 to 60 percent of the variance in average of students' achievement in assessment. Richardson (2008) reveals that students in urban areas performed better than those in rural areas. The researcher suggests that the availability of enough qualified teachers must have been a determinant for students' performance. However, in Kenya, some schools in the rural areas have performed better than 
their urban counterparts (Owoeye \& Yara, 2011). Maundu (1986) concludes that there was significant correlation between teacher qualification and pupil performance in Kenya. The good performance was attributed to excellent instructions given by qualified teachers in addition to other inputs. Maundu (1986) establishes that teachers who had graduated from Kenya Science Teachers College were more practically oriented than those who had degrees from public universities.

Laczko \& Berliner (2001) assert that the impact of certification status on student achievement in two large urban school districts in the United States of America. These school districts provided information about teachers hired for the 1998-1999 and 1999-2000 school years. Information included the school where they were currently teaching, the grade level taught, the teacher's certification status, highest degree earned, date and institution where it was achieved, age, and number of years teaching experience.

It has been evidenced that in many countries, teacher qualifications that are considered to be related to student learning have become desirable targets of teacher education reform. Some of these reforms call for the professionalization of teacher education by making it longer, upgrading it to graduate programs, and regulating it through mechanisms of licensure, certification, and promotion aligned with standards (Darling-Hammond et al., 2001; 2002). Findings related to teachers' academic degrees (for example; bachelors or masters among others) are inconclusive. Some studies suggest positive effects of advanced degrees (Rice, 2003; Wayne \& Youngs, 2003). Some argue that the requirement of a second degree raises the cost in terms of teacher education and the time it involves and may prevent quality candidates from choosing this profession (Murnane, 1996). This characteristic is related to the subject-matter knowledge teachers acquire during their formal studies and preservice teacher education courses. The evidence gained from different studies is contradictory.

\section{TEACHER EXPERIENCE AND STUDENT ACADEMIC ACHIEVEMENT}

Teacher experience has a significant effect on pupil performance in primary schools and at upper secondary level. Experienced teachers have a richer background of experience to draw from and can contribute insight and ideas to the course of teaching and learning, are open to correction and are less dictatorial in 
classroom. Teachers' experience and student achievement was that students taught by more experienced teachers achieve at a higher level, because their teachers have mastered the content and acquired classroom management skills to deal with different types of classroom problems (Gibbons et al., 1997). Furthermore, more experienced teachers are considered to be more able to concentrate on the most appropriate way to teach particular topics to students who differ in their abilities, prior knowledge and backgrounds (Stringfield \& Teddlie, 1991).

Teachers attendance of in - service training are one of the indicators of experience. Teachers' motives to attend in-service training can be manifold e.g. increase in salary, career planning, keeping up with developments, filling in lacunae, removing insecurity and meeting colleagues. In the Science Education Project in South Africa (SEP), the objectives were mainly formulated by the developers after having consulted various experts who had experience with Education in Africa. The teachers in this program had been and did not have any experience with practical work. Only in a later stage of their in-service training course they had a better idea of the possible content and methods, did formulating objectives of their own lessons become part of the program (Fullan, 1992).

In contrast, a small number of studies suggest that teacher experience effects may be evident for a longer period of time. Murnane \& Phillips (1981) state that experience had a significant positive effect on elementary student achievement among teachers during their first seven years of teaching. Ferguson (1991) reveals that at the high school level, students taught by teachers with more than nine years of experience had significantly higher test scores than students whose teachers had five to nine years of experience.

Rivers \& Sanders (2002) suggest that teacher' effectiveness increases dramatically each year during the first ten years of teaching". In the extreme case, Clotfelter et al., (2007) found evidence of growing teacher effectiveness out to 20 or more years in their analyses of North Carolina teacher data, although more than half of the gains in teacher effectiveness occurred during the first few years of teaching.

\section{METHODOLOGY}

The teacher characteristics investigated were; qualifications and experience. The study was conducted in Ogan Komering Ulu in the year 2013. The study sampled 20 Senior High Schools in the district from a total population of 20. 
The respondents were teachers from 20 senior high schools within the district. Simple random sampling was used to select one teacher in each school.

The study adopted a causal - comparative research design. Role (2010) suggests that the cause - effect linkage is made logically as the research process proceeds. Therefore, in this study teacher characteristics could be a factor influencing student academic achievement.

A demographic data used to find out the qualification and experience of teachers'. An online questionnaire of big five personality was used as instrument for data collection and data collected was analysed using both descriptive and inferential statistics. A students' Academic Achievement taken from the national examination score which categorized into below, average and high scores.

In distinguishing one person from another, Psychologist have literally come up with over a thousand traits as suggested by Moore \& Griffen (2010). This is as a result of personality trait being a primary subject of personality research in the UK and USA (Mullins: 2007). With a body of evidence that captures five (5) distinct differences between people. The big five framework is essential to be understood by teachers, and if they can also asses this traits on their employees, they would be in a better position to explain why employees behave the way they do sometimes. This will further help teachers in managing people to aid performance.

Table 1: Background characteristics of the teachers

\begin{tabular}{|c|c|c|c|}
\hline Variable & Labels & Frequency & Percent \\
\hline \multirow[t]{2}{*}{ Gender } & Male & & \\
\hline & Female & & \\
\hline \multirow[t]{4}{*}{ Age } & Below 30 years & & \\
\hline & $31-39$ years & & \\
\hline & 40-49 years & & \\
\hline & 50 years and above & & \\
\hline \multirow{2}{*}{$\begin{array}{l}\text { Highest educational } \\
\text { qualification }\end{array}$} & Masters of education & & \\
\hline & Bachelor of education & & \\
\hline \multirow[t]{5}{*}{ Professional experience } & $1-5$ years & & \\
\hline & $6-10$ years & & \\
\hline & 11-15 years & & \\
\hline & $16-20$ years & & \\
\hline & Over 20 years & & \\
\hline \multirow[t]{2}{*}{ Certification } & Certified & & \\
\hline & Uncertified & & \\
\hline
\end{tabular}


In this study, a cross tabulation was carried out between teacher qualification indicators (degree, diploma, and A - Level) on rows against student academic achievement average.

\section{FINDINGS}

\section{Relationship between teacher qualifications and students' academic achievement}

The first objective of this study was to determine the relationship between teacher qualification and student academic achievement. To achieve this objective, a cross tabulation was carried out between teacher qualification indicators (degree, diploma, and A - Level) on rows against student academic achievement average (for 2013) on the column side.

Table 2: Relationship between teacher's qualification and students' academic achievement

\section{Student academic achievement}

\begin{tabular}{llllll}
\hline & High & Average & Below & Total \\
Teachers & Degree Count & 4 & 3 & 6 & 13 \\
qualification & $\%$ & $30.8 \%$ & $23.1 \%$ & $46.2 \%$ & $100.0 \%$ \\
& Diploma Count & 1 & 3 & 1 & 5 \\
& $\%$ & $20.0 \%$ & $60.0 \%$ & $20.0 \%$ & $100.0 \%$ \\
& Untrained Count & 0 & 0 & 2 & 2 \\
Total & $\%$ & $0 \%$ & $0 \%$ & $100.0 \%$ & $100.0 \%$ \\
& Count & $\mathbf{5}$ & $\mathbf{6}$ & $\mathbf{9}$ & $\mathbf{2 0}$ \\
& $\mathbf{\%}$ & $\mathbf{2 5 \%}$ & $\mathbf{3 0} \%$ & $\mathbf{4 5 \%}$ & $\mathbf{1 0 0} \%$ \\
\hline
\end{tabular}

(Source: Research Data 2013)

The results on the contingency reveal that as the level of education increases, the student performance in increased. The result implies that teacher academic qualification influence student's academic achievement.

H01: There is no significant relationship between teacher academic qualification achievements with students' academic achievement 
Table 3: Teacher qualification and performance chi-square tests

\begin{tabular}{lccc}
\hline & Value & df & Asymp. Sig. (2-sided) \\
\hline Pearson Chi-Square & $5.074 \mathrm{a}$ & 4 & 0.280 \\
Likelihood Ratio & 5.676 & 4 & 0.225 \\
N of Valid Cases & 20 & & \\
\hline
\end{tabular}

a. 8 cells $(88.9 \%)$ have expected count less than 5 .

The minimum expected count is .50 .

(Source: Research Data 2013)

The results suggest that; at $\left.\chi^{2}(4, \mathrm{~N}=20)=5.07, \mathrm{p}=0.28\right)$ teacher qualification and student academic achievement is not statistically significant. We therefore accept the null hypothesis. The results illustrate that teacher qualification does not influence student's academic achievement.

\section{Relationship between teachers experience and students' academic achievement}

The second objective of the study was to investigate the relationship between English teachers' experience (years of teaching, attendance of in-service courses and setting and marking of national examinations) and students' academic performance in English. Experience is highly valued in the teaching profession, more so than in many other professions. With experience playing such a major role in Senior High Schools complex cost-benefit considerations, it makes sense to consider how teacher experience influences student achievement. 
Table 4: Relationship between teaching experience and student academic achievement

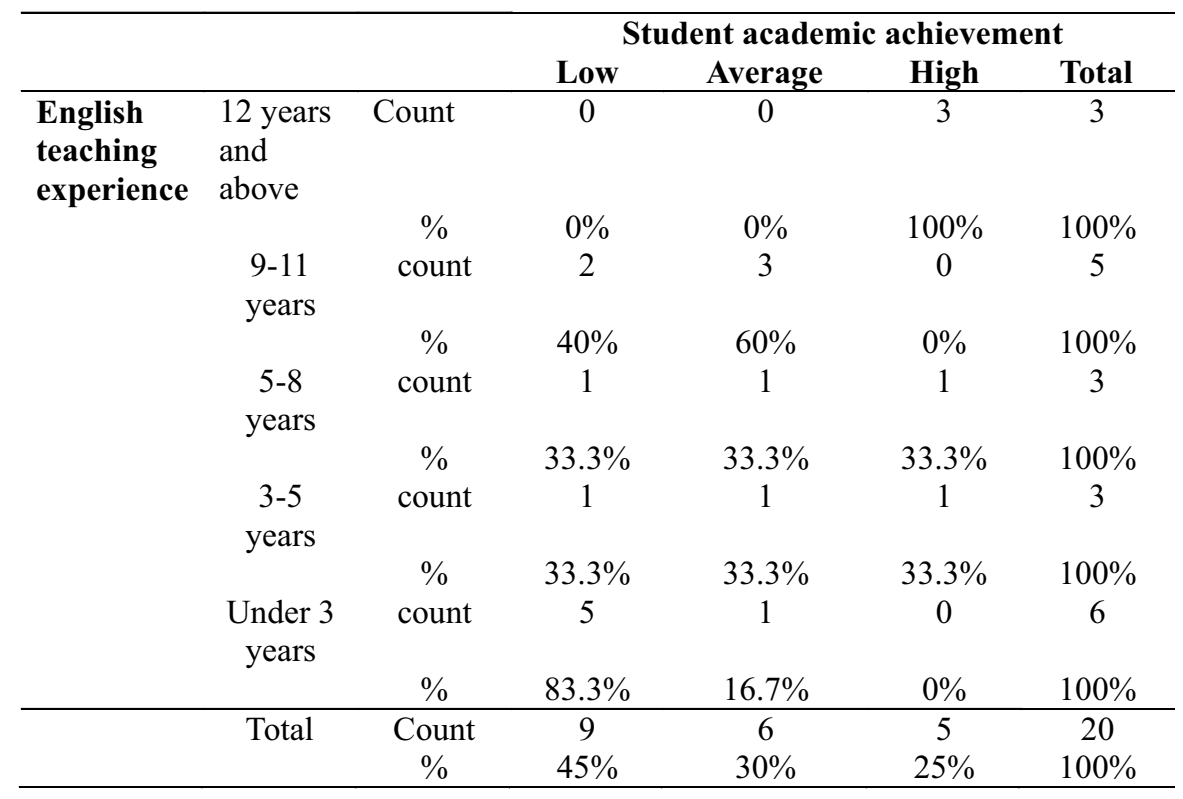

(Source: Research Data 2013)

From the Table 3, it is clear that as the number of years of teaching progresses, students' academic achievement increases. This is evident with the fact that teachers having less than 3 years of experience, students' academic achievement is below average $(83.3 \%)$ as compared to teachers who have 12 years and above teaching experience whose students' academic achievement is high (100\%). Therefore, it can be concluded that as the number of teachers' years of experience progresses, student academic achievement increases and vice versa.

\section{H02: There is no significant relationship between teacher experience and student academic achievement}

To test the significance of these results, a chi square analysis was carried out and the probability error was set at 0.05 levels. 
Table 5: Teaching experience and student academic achievement Chi-square tests

\begin{tabular}{lccc}
\hline & Value & df & Asymp. Sig. (2-sided) \\
\hline Pearson Chi-Square & $15.963 \mathrm{a}$ & 8 & 0.43 \\
Likelihood Ratio & 17.364 & 8 & .027 \\
N of Valid Cases & 20 & & \\
\hline
\end{tabular}

a. 15 cells $(100.0 \%)$ have expected count less than 5 .

The minimum expected count is .75 .

(Source: Research Data 2013)

The results report that; at $(\chi 2(8, \mathrm{~N}=20)=15.963, \mathrm{p}=0.043)$, the null hypothesis is rejected and it is concluded that there is statistically significant relationship between the number of years teachers have been teaching the subject and student academic achievement.

This study investigated the influence of teacher characteristics and students' academic achievement in Senior High Schools. The findings reveal that student academic achievement (in 2013) was below average for $45 \%$ of the schools, 6(30\%) achievement was on average while 5(25\%) of schools had high student academic achievement. The poor performance was attributed to inadequate number of teachers in most Senior High Schools within the District. On teacher qualification, the study established that $65 \%$ of teachers were degree holders, $25 \%$ had diploma certificates while only $10 \%$ were untrained.

\section{CONCLUSION}

Cross tabulation results suggest that there was no difference in performance between teachers who had degrees or diploma suggesting that teacher qualification did not result to increased student academic achievement.

1. The chi square result illustrate that there is no significant result between teacher qualification and student academic achievement. Participation of teachers in professional development programmes has benefited a lot with improvisation of teaching methods. Teachers with 3 years and above of teaching, recorded higher student academic achievement. 
2. This led to rejection of null hypothesis that there was no significant relationship between teacher experience and student academic achievement.

Since this study only focused on teacher qualification and student academic achievement, it will be better for further research to relate not only the teachers' characteristics but also the parents' involvement to have better results.

\section{REFERENCES}

Adesoji, F.A. \& Olatunbosun, S.M. (2008) Student, Teacher and School Environment Factors As Determinants of Achievement in Senior Secondary School Chemistry in Oyo State, Nigeria The Journal Of International Social Research Volume 1/2 pp 13-34.

Adu, E. O \& Olatundun, S. O. (2007) "Teachers' Perception of Teaching as Correlates of Students' Academic Performance in Oyo State Nigeria" Essays in Education, 20: 57-63.

Akinsolu, A.O. (2010)Teachers and Students' Academic Performance in Nigerian Senior High Schools: Implications for Planning Florida Journal of Educational Administration \& Policy Volume 3, Issue 2 pp86-103

Ali , A.A.(2009) The impact of teacher wages on the performance of students: e vidence from PISAmpra.ub.unimuenchen. de/.../Impact_of_teacher_wages_on_the_...

Ashton, P. (1996). "Improving the Preparation of Teachers" Educational Researcher, 25 No. 9:21-22.

Clotfelter, C. T., Ladd, H. F., \& Vigdor, J. L. (2007) Teacher Credentials and Student Achievement in High School: A Cross-subject Analysis with Student Fixed Effects. Working Paper 11 Washington, DC: Urban Institute, National Center for Analysis of Longitudinal Data in Education Research.

Coonen, H. W. A. M. (1987). Didactiek Van den nascholing: Een introductic (Methodology of In-service Training; An Introduction). Den Bosch: KPC.

Darling-Hammond, L. (1998) Teacher and Teaching; Testing Policy Hypothesis from a National Commission Report. In: Educational Researcher. Vol 27(1):5-15. 
Darling-Hammond, L., Berry, B., \& Thorenson, A. (2001) Does teacher certification matter? Evaluating the evidence. Educational Evaluation and Policy Analysis, 23(1) 57-77.

Darling-Hammond, L., Chung, R., \& Frelow, F. (2002) Variation in teacher preparation: How well do different pathways prepare teachers to teach? Journal of Teacher Education, 53(4), 286-302.

Ferguson, R. F. (1991). Paying for Public Education: New Evidence on how and why Money Matters Harvard Journal of Legislation, 28:465-498.

Fullan, M. G. (1992). Successful School Improvement: The Implementation Perspective and Beyond. Buckingham. Open University press, 1992.

Gibbons S, Kimmel, H \& O'Shea, M. (1997) Changing Teacher Behaviour through Staff Development:Implementing the Teaching and Content Standards in Science School Science and Mathematics; 976 (1):302-340.

Goldhaber, D. D., \& Brewer, D. J. (2000) "Does Teacher Certification Matter? High school Teacher Certification Status and Student Achievement" Educational Evaluation and Policy Analysis, 22 (2):129-145.

Hardy, I. \& Smith, E. (2006) 'Contesting Tertiary Teaching Qualification: An Australian Perspective' Teaching in Higher Education, Vol 11(2):337-350.

Huang, F.L. \& Moon, T.R. (2009) Is experience the best teacher? A multilevel analysis of teacher characteristics and student achievement in low performing schools Educ Asse Eval Acc 21:209-234

Laczko-Kerr, I., \& Berliner, D. C. (2002). "The Effectiveness of "Teach for America" and other Under-certified Teachers on Student Academic Achievement: A Case of Harmful Public Policy." Education Policy AnalysisArchives, 10(2):1-52.

L a i, E. R. ( ( $\left.\begin{array}{llll}2 & 0 & 1 & 1\end{array}\right) \quad$ C o 11 a b o r a t i o $n$ www.pearsonassessments.com/hai/images/.../Collaboration-Review.pd...

Maundu, J. N. (1986). Student Achievement in Science and Mathematics: A Case of Extra Provincial, Provincial, and Harambee Senior High Schools in Kenya. PhD Thesis. McGill University, Montrea

Monk, D. H. (1994) "Subject Area Preparation of Secondary Mathematics and Science: Teachers and Student Achievement." Economic of Education Review, 13(1):125-145. 
Moorhead, G., \& Ricky, W. Griffin. (2010). Organizational behavior: Managing people and organization. Australia: Cengage Learning.

Mugenda, O. M. A. \& Mugenda, A.G. (1999). Research Methods: Quantitative and Qualitative Approaches. Nairobi: African Center for Technology Studies (ACTS) Press.

Murnane, R.J. and Phillips, B.R. "What Do Effective Teachers Of Inner-City Children Have In Common?" Social Science Research 10, no. 1 (1981): 83-100.

Owoeye, J. S. \& Yara, P. O. (2011) School Location and Academic Achievement of Secondary School in Ekiti State, Nigeria Asian Social Science Vol. 7, No. 5;pp 170-175

Patrick, B. (2005). Why children must not be Compared In Education Sight for Quality Information Magazine, Kenya

Putrawan, et.al. (2012). Validating personality as determinant factors of elementary school principals performance. Proceeding of the 1st International Seminar on Quality and Affordable Education, 21-23 May, 2012. Jakarta: Jakarta State University.

Rice, J. K. (2003). Teacher Quality: Understanding the Effectiveness of Teacher Attributes. Washington, DC: Economic Policy Institute.

Richardson, A. R. (2008) An Examination of Teacher Qualifications and Student

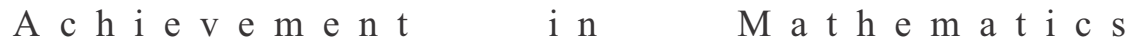
etd.auburn.edu/etd/bitstream/handle/.../Richardson_Antoine_8.pdf

Rivers, C. \& Sanders, M. (2002) Statewide Class-size Studies Prime Time and Star, Tennessee's Project Star Dallas Texas.

Role, E. M. (2010). Handbook of Social and Educational Research Methods University of Eastern Africa, Baraton.

Rowan, B. Chaing, F.S., \& Miller, R.J. (1997) 'Using research on employees' performance to study the effects of teachers on students' achievement" Sociology of Education, 70(1):256285.

Ruthland, S. K. \& Bremer, C. D (2002) 'Alternative Teacher Certification Procedures and Professional Development Opportunities for Career and Technical Education Teachers' Washington D.C.: ERIC Clearinghouse on Teacher Education. 
Stringfield, S. \& Teddlie, C. (1991) School, Classroom and students' Level Indicators of Rural School Effectiveness A Journal of Research in Rural Education, 7(1):15-28.

Wayne, A. J. \& Youngs, P. (2003) Teacher Characteristics and Student Achievement Gains: A Review. Review of Educational Research, 73 (3): 89-122.

Wirth, K.R. \& Perkins, D. (2013) Learning to learn www.macalester.edu/academics/geology/wirth/learning.doc.

\section{ONLINE QUESTIONNAIRE RESULT}

\section{Change language: English Deutsch Español Nederlands}

\section{THE BIG FIVE}

\section{PERSONALITY TEST}

\section{Your Results}

Closed-Minded $\mid \boldsymbol{O}$

Disorganized | Conscientious

Introverted $\mid$ Extraverted

Disagreeable | $\mid$ Agreeable

Calm / Relaxed |_ Nervous / High-Strung

Link to your results! Email your results to a friend! 


\section{What aspects of personality does this tell me about?}

There has been much research on how people describe others, and five major

dimensions of human personality have been found. They are often referred to as the OCEAN model of personality, because of the acronym from the names of the five dimensions.

\section{Openness to Experience/Intellect}

High scorers tend to be original, creative, curious, complex; Low scorers tend to be conventional, down to earth, narrow interests, uncreative.

I= experiences.

\section{Conscientiousness}

High scorers tend to be reliable, well -organized, self disciplined, careful; Low scorers tend to be disorganized, undependable, negligent.

I You are very well -organized, and can be (Your percentile: relied upon.

\section{Extraversion}

High scorers tend to be sociable, friendly, fun loving, talkative; Low scorers tend to be introverted, reserved, inhibited, quiet.

You are relatively social and enjoy the company of others.
(Your percentile:

\section{Agreeableness}

High scorers tend to be good natured, sympathetic, forgiving, courteous; Low scorers tend to be critical, rude, harsh, callous.

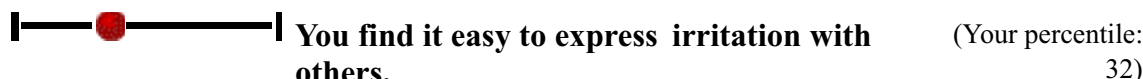

\section{Neuroticism}

High scorers tend to be nervous, high -strung, insecure, worrying; Low scorers tend to be calm, relaxed, secure, hardy.

\section{limis}

You aren't particularly nervous, nor calm. (Your percentile: 


\section{What do the scores tell me?}

In order to provide you with a meaningful comparison, the scores you received have been converted to "percentile scores." This means that your personality score can be directly compared to another group of people who have also taken this personality test.

The percentile scores show you where you score on the five personality dimensions relative to the comparison sample of other people who have taken this test on-line. In other words, your percentile scores indicate the percentage of people who score less than you on each dimension. For example, your Extraversion percentile score is 74 , which means that about 74 percent of the people in our comparison sample are less extraverted than you -- in other words, you are rather extroverted. Keep in mind that these percentile scores are relative to our particular sample of people. Thus, your percentile scores may differ if you were compared to another sample (e.g., elderly British people). 